\title{
The Enforcement of Foreign Arbitral Awards in the GCC Countries: Focus on Kuwait
}

\author{
Saad Badah $^{1}$ \\ ${ }^{1}$ Law School, Brunel University, London, UK \\ Correspondence: Saad Badah, Law School, Brunel University, London, UK. Tel: 9-659-920-0747. E-mail: \\ SaadAHJ.Badah@brunel.ac.uk; sa3d51@hotmail.com
}

Received: March 4, $2014 \quad$ Accepted: March 14, $2014 \quad$ Online Published: April 15, 2014

doi:10.5539/ilr.v3n1p24 URL: http://dx.doi.org/10.5539/ilr.v3n1p24

\begin{abstract}
Kuwait is a member country of the Gulf Cooperation Council (GCC). As with the other countries in the GCC, Sharia law informs its laws. The use of the New York Convention (NYC) to resolve disputes has come into conflict with Sharia law if the choice of law is from another system of laws. This means that Kuwait has followed the procedures of the NYC, under the principle of reciprocity, as the main ground for disqualifying enforcement of foreign arbitral awards in Kuwait.

The legislation and practices that guide the enforcement and recognition of foreign arbitral awards are not only limited to the international standards under the NYC and the United Nations Commission on International Trade Law (UNCITRAL) Model Law. The domestic laws adopt the international standards as well as incorporating the reservation clauses and the reciprocity aspects. The article also seeks to elucidate the grounds that do not inform the enforcement of foreign arbitral awards. These include procedural and substantive technicalities that arise from non-adherence to the law, the competency of the arbitrators, the legality of the arbitral awards, as well as other stipulations in the Code of Civil and Commercial Procedure (CCCP). This article examines the application of arbitral law in the Middle East and how effective this is in settling trade disputes. A broader perspective will also be taken as this article will consider the issues that have been associated with the application of arbitral law in preference to conservative land laws in the region.

The place of arbitral awards that are rendered abroad is also a focus of the article, as are the procedures and conditions that are considered in enforcing them in Kuwait. Arbitrability and non-arbitrability of foreign arbitral awards is also examined based mainly on the choice of law or where the arbitral award is from a country that does not enforce or recognise arbitral awards declared against it.
\end{abstract}

Keywords: arbitral award, enforcement, Kuwait, New York Convention, recognition

\section{Introduction}

Arbitration under international law is commonly referred to as a formal dispute settlement mechanism, ${ }^{1}$ similar in many ways to common judicial procedures. ${ }^{2}$ In line with this, arbitration involves having a binding determination of a dispute by a third party who is competent and well-versed, with knowledge to declare a dispute as final according to a set of established legal principles. ${ }^{3}$ The whole issue of flexibility is well addressed by the parties involved in the dispute with an arbitration tribunal being set up, both on an ad hoc or permanent basis, such as the Permanent Court of Arbitration. ${ }^{4}$ Interestingly, when it comes to the concept of arbitration and how it applies in Kuwait it can be argued that the concept of dealing with disputes in a pre-determined way, agreed between the parties, is a system that has been in place under Islam for over 1400 years and is one that is not entirely different to the modern arbitration approach.

The concept of arbitration is discussed in the Holy Qu'ran and this suggests that maintaining a private mechanism for dealing with commercial disputes is important in a variety of situations and particularly in those jurisdictions that place a heavy reliance on moral and religious obligations. Whilst this has now been enshrined in Article 173 of

\footnotetext{
${ }^{1}$ Ragib W, 'Hal Altahkeem Nao'min Alqada'?' [Is Arbitration a type of Litigation?] (1993) 17(1) University of Kuwait Law Journal 131.

2 Rothwell D, Kaye S, Akhatkavari A \& Davis R, International law: Cases and Materials with Australian Perspectives (Cambridge

University Press 2011) 254.

3 ibid 673.

${ }^{4}$ [1997] 1907 Convention for the Pacific Settlement of International Disputes ( ATS 6 (Hague 1)
} 
Kuwait's CCCP, the ethos and theory of arbitration as a historic doctrine should not be ignored and will be considered throughout this analysis. This article has ultimately been written to consider the dynamics of arbitration law across the Middle East and the relationship between medieval trade laws and modern arbitration law.

Despite the recognition of arbitration, the Judicial Arbitration Law No. 111995 (JAL) does not provide a precise definition of a foreign arbitration award. However, it outlines the procedure whereby a panel of arbitrators can be formed in the Court of Appeal comprising at least three judicial officers and two arbitrators to be chosen in each dispute for each party. ${ }^{5}$

Article 2 of the NYC explains that arbitral awards "shall include not only awards made by the arbitrators appointed for each case but also those made by permanent arbitral bodies to which the parties have submitted". ${ }^{\text {. This }}$ definition encompasses all kinds of arbitral awards that parties signatory to the Convention are included in. However, Kuwait only enforces arbitral awards subject to reciprocity. Terms related to the definition of an arbitral award, according to the Convention, also include the "agreement in writing" which is an arbitration agreement signed by the parties or an arbitration clause contained in an exchange of letters. ${ }^{8}$

\section{Background}

Article 1(2) of the NYC defines an arbitral award to mean that it will not be limited to including awards that are made by the arbitrators appointed in each case but also to those that are made by permanent arbitral bodies to which the parties are submitted. ${ }^{9}$ This means that an arbitral award ought to be regarded as such, not in consideration of whether there is an agreement.

The arbitration laws in Kuwait are not based on a comprehensive and specific regulation but rather on the Civil and Commercial Procedure Law; neither is it dependent on the UNCITRAL Model Law. ${ }^{10}$ Thus, the definition of an arbitral award would depend on the choice of law.

In February 1995, a novel judicial body came into being. This entity was an arbitration tribunal for civil and commercial issues in Kuwait. This arbitration tribunal, as provided by the law, is comprised of a three judge panel selected from the Court of Appeals and 2 arbitrators. The latter are appointed by the parties to the arbitration. This court has been provided with exclusive jurisdiction over disputes between private corporate bodies, public authorities, ministers of the government and state owned corporations. ${ }^{11}$ The law also shows that a foreign arbitral award also follows the same system as a domestic arbitral award. It is important to point out that some companies established in Kuwait have deemed it necessary to include arbitration clauses in their constitution in order to govern any disputes which arise in the course of trade activities.

Kuwait has also adopted the CCCP that was first enacted and came into effect in $1980,{ }^{12}$ as well as amendments to other legislation that are crucial for the enforcement of awards. Moreover, being a GCC country, it has incorporated Sharia law as well as treaties, such as the NYC, to give effect to how foreign arbitral awards are enforced.

The NYC is, in principle, applicable to each and every arbitral award. All the same, certain reservations are permitted to the signatories under Article X. Thus, a member state has the option of recognising and enforcing an arbitral award only if it has been made in another contracting state. This is on the basis of reciprocity. In addition, a member state can declare that it will restrict the application of the Convention to disputes arising from legal relationships that are deemed to be commercial under the laws of the country making such declarations. ${ }^{13}$ As a consequence, two important reservations have emerged.

The reciprocity reservation which permit a country to refuse recognition and enforcement of arbitral awards until, and unless, the awards have been rendered in a contracting state, was adopted in Kuwait's reservation clause, as well as the commercial reservations which allow a state to restrict the application of the Convention to commercial disputes, as determined by its domestic laws. ${ }^{14}$ These reservations are crucial to Kuwait as they ensure that it is only possible to recognise arbitral awards made by states that recognise arbitral awards from Kuwait.

\footnotetext{
${ }^{5}$ Abdullah Kh Al-Ayoub \& Associates, 'Enforcement of Foreign Judgments' < http://www.al-ayoub.org/legal3.html> accessed 18 March 2014.

${ }^{6}$ Convention on the Recognition and Enforcement of Foreign Arbitral awards (NYC) 1958, art 2.

${ }^{7}$ ibid art 2.2.

8 ibid

${ }^{9} \mathrm{NYC} 1958$, art 1.2 .

${ }^{10}$ S Herbert, Country Factsheet (2nd edn, Dlaiss Lutz and Stibbe 2009) 3.

${ }^{11}$ P Nacimiento, New law on civil and commercial arbitration (1996) International Commercial Litigation 46.

12 Kuwait Code of Civil and Commercial Procedure 1980, 38.

13 ibid 616.

14 ibid 620 .
} 
The place of countries that declare arbitral awards against Kuwait and do not consider themselves to enforce Kuwait's foreign arbitral awards is not well determined and parties to this can fail to have the awards enforced. There are a number of grounds that need to be proved by an opposing party through recognition and enforcement in Kuwait. The incapacity of a party to an arbitration proceeding or an arbitration agreement ought to be determined by a competent arbitral tribunal. Moreover, the principles of natural justice need to have been upheld or this can be a ground for not enforcing the arbitral award. A fair hearing is crucial and this is another ground for refusal of recognition as a principle of natural justice because it prejudices the interest of the parties to the arbitration agreement. Additionally, where the arbitrator uses excessive powers in making the arbitration award or the arbitration tribunal has no jurisdiction to determine the dispute, then the court of Kuwait cannot enforce such an agreement. Lastly, a ground for refusal of enforcement of an arbitral award arises in instances where there are adverse procedural irregularities that make the arbitral award entirely unenforceable by any court of a competent jurisdiction. $^{15}$

Any issue or subject matter submitted to arbitration must be capable of being subjected to arbitration. In addition, a foreign arbitral award can be rejected for a number of reasons. First, the subject matter of the dispute is incapable of being resolved by arbitration, as per the law of that country. Second, the public policy of that country would be violated if the foreign arbitral award were to be granted recognition and enforcement. ${ }^{16}$

Countries in dispute have, on several occasions, chosen to use arbitration as the best way to solve their dispute based on the fact that it is consensual, private and quite effective compared to a court process. The place of arbitration is left to the parties to elect ${ }^{17}$ and this, in some jurisdictions, can be a ground for setting aside an arbitral award. ${ }^{18}$ The place of arbitration must be in a neutral location and should, as far as possible, be unconnected to either of the disputing countries or parties.

Despite the many inadequacies in local laws, ultimately, there appears to be a logical reason to harmonize these laws with arbitration awards. In addition, the place of arbitration should be equally convenient to access for these countries and should provide the necessary facilities for hearings and meetings required in a dispute between nations. ${ }^{19}$ In the GCC countries (Bahrain, Kuwait, Oman, Qatar, Saudi Arabia and the UAE), foreign arbitral awards are enforced on the basis of domestic laws or treaties; therefore, the domestic laws take precedence over other, foreign laws. In addition to bilateral treaties, there are multilateral conventions relating to the enforcement of foreign arbitral awards. These are: the Arab League Convention which was ratified on 14 September 1952; the New York Convention of 1958; and the World Bank Convention on the Settlement of International Disputes of $1965 .{ }^{20}$ It is to be noted that only Kuwait is a party to the Arab League and NYC; and only Saudi Arabia to the Arab League and World Bank Conventions.

Kuwait realised the usefulness of ratifying the NYC after it emerged victorious in the Minister of Public Works of the Government of Kuwait $v$ Snow and Partners ${ }^{21}$ case. It would be to the benefit of all concerned if the GCC countries were to ratify these conventions. ${ }^{22}$ A mere handful of the GCC countries have domestic laws of sufficient modernity to deal with the subject matter of foreign arbitral awards. This proves to be a major hindrance to the enforcement of such awards. In general, the enforcement of foreign arbitral awards is similar to the enforcement of foreign judgements. For instance, in Kuwait and Bahrain, enforcement of a foreign arbitral award necessitates the satisfaction of certain conditions. ${ }^{23}$ The reciprocity reservation is the first aspect to be considered before any foreign arbitral award is enforced in Kuwait. This is because some contracting states choose only to elect and enforce awards from other particular countries. Secondly, the due process of service ought to have been followed to make the arbitral award enforceable. Thirdly, the foreign arbitral award has to be the final judgement pronounced by a competent arbitral tribunal in that particular state. Moreover, the public policy, as well as morality should not be violated by the declaration made in the arbitral award. Finally, the case determined in the award should be capable of being subjected to arbitration, as provided in the domestic laws. ${ }^{24}$

The foreign arbitral award cannot be enforced if it cannot be enforced in the jurisdiction where it was made. The states of Qatar and Oman provide no statutory laws or regulations relating to the enforcement of foreign arbitral

\footnotetext{
15 ibid 465 .

${ }^{16}$ ibid 124

${ }_{17}^{17}$ P Geoffrey, 'Settlement of International Disputes: The "Rainbow Warrior” Affair' (1989) Commonwealth Law Bulletin 586.

${ }^{18} \mathrm{~J}$ Collier \& V Lowe, Dispute Settlement in the UN Convention on the Law of the Sea (Cambridge University Press 2005) 565.

19 ibid 156

${ }^{20}$ ibid 13.

${ }^{21}$ Minister of Public Works of the Government of Kuwait v Sir Fredrick Snow and Partners [1981] 1 Lloyd's Rep 656

${ }_{22}$ Al-Baharna HM, 'International Commercial Arbitration in Perspective' (1988) 3(1) Arab Law Quarterly 3.

${ }^{23}$ ibid 4.

24 ibid 11 .
} 
awards, thus making it difficult to determine the enforceability of any foreign arbitral award. Consequently, a retrial of the dispute has to be undergone prior to enforcing a foreign arbitral award. ${ }^{25}$ The situation in the UAE is all the more complex due to the federal nature of the entity and the absence of relevant statutory law in the constituent countries. From the federal perspective, an arbitral award made in one of the members of the emirate has to be enforced by any other member. Such enforcement has to be done without examining the merits of the case, subject to certain conditions being satisfied. ${ }^{26}$

Arbitration clauses show variations over time, place and circumstances. This is evident from a perusal of the GCC countries' oil agreements. Since independence from colonial powers, tremendous changes have taken place in the Gulf countries and these are reflected in the arbitration clauses. During this period, arbitration was governed by the domestic laws of the concerned nation. Prior to independence, arbitration was supervised by an umpire who was appointed by the British political agent. ${ }^{27}$

Arbitration in the context of private parties with regard to international trade agreements transpires according to one of the internationally available sets of arbitration rules. These are the arbitration rules of the ICC, UNCITRAL and the Euro-Arab Chambers of Commerce. Amongst these, the arbitration rules of the ICC have been very popular. ${ }^{28}$ However, the UNCITRAL rules have gradually gained international acceptance. This has been significant in disputes between parties hailing from different continents. ${ }^{29}$

Several commendable efforts have been made at the international level, under the auspices of the United Nations, to unify the rules and procedures related to the enforcement of foreign arbitral awards. ${ }^{30}$ The foremost amongst these is the NYC. This Convention labours under the disadvantage of containing provisions of a vague character. All the same, many parties have benefited from it. ${ }^{31}$ There have been suggestions from several quarters that the GCC countries should adopt the required measures that will hasten the process of acceptance of this Convention. Several countries of the Middle East have not ratified the NYC and, in these countries, foreign arbitral awards are enforced in accordance with the local laws of the concerned nation. The few exceptions to this untenable situation are Bahrain and Kuwait. These countries have enacted specific procedures, via their Civil and Commercial Procedure Acts, which deal with the enforcement of foreign arbitral awards. ${ }^{32}$

The NYC's objective is to promote arbitration and the enforcement of arbitral awards. However, some of its provisions are couched in unclear language. For instance, Article V of the Convention specifies the grounds on which a foreign arbitral award can be denied recognition and enforcement. One of the grounds for such refusal is annulment of the award by a court of the country, wherein or under whose laws the award had been made. It is also important to note that Article VII of the Convention stipulates that a foreign arbitral award is enforceable to the full extent of the laws of the nation in which its enforcement is desired. ${ }^{33}$ In accordance with Article $\mathrm{V}$ of the Convention, a foreign arbitral award can be refused recognition and enforcement only if substantial irregularities had transpired during the arbitral proceedings.

Some important examples of such irregularities are the inadequate serving of notice of proceedings or of the appointment of an arbitrator; or the denial of a fair hearing to a party. ${ }^{34}$ Moreover, a court may refuse to accord recognition and enforcement of a foreign arbitral award if the procedures employed by the arbitral authority or its composition were contrary to the underlying arbitration agreement. Recognition and enforcement of an arbitral award can also be refused if the arbitration agreement is invalid or the incapacity of a party is established. ${ }^{35}$ Furthermore, a court can reject an award in which the arbitrators had decided upon an issue that had not been submitted to them. In addition, a court can reject an arbitral award if the related dispute was not arbitrable under the laws of its country or if recognition and enforcement of the award would be contrary to its national public policy. ${ }^{36}$

Article V of the Convention has been interpreted by some scholars as permitting courts to enforce foreign arbitral awards that had been rejected in the country of origin. This arises due to the employment of the word "may" in the

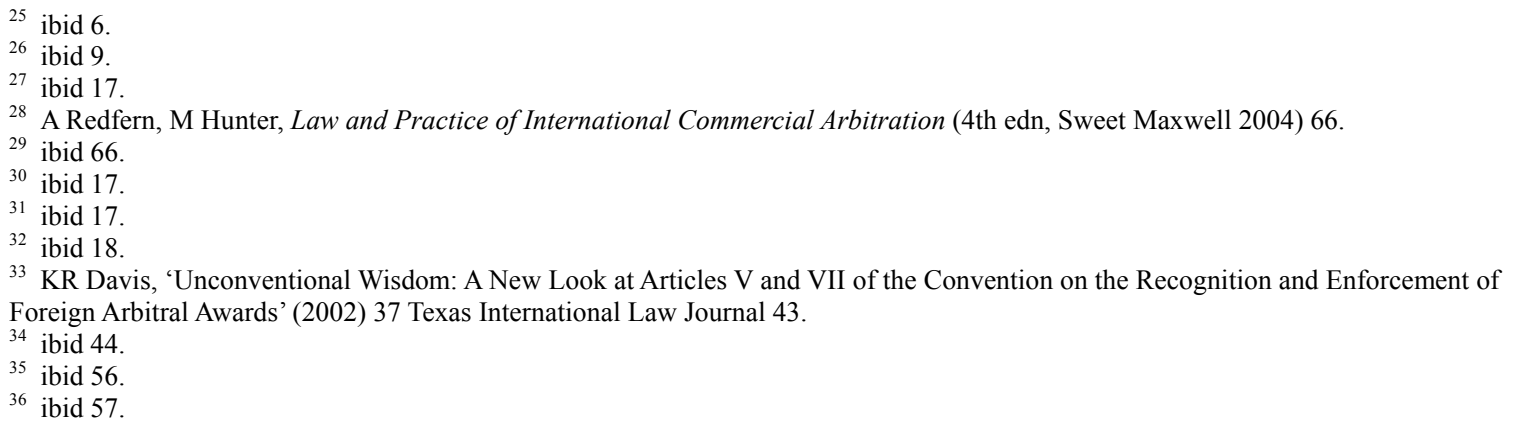


said Article. On the other hand, Article VII of the Convention uses the word "shall" which has been construed to make it mandatory to enforce a foreign arbitral award. This is to be done when the domestic law bestows more favourable rights in comparison to the award. ${ }^{37}$ On the other hand, some other scholars contend that Article VII of the Convention does not mandate that more favourable rights are to be imposed. These scholars argue that Article $\mathrm{V}$ grants discretion to the courts with which they can enforce or refuse to enforce awards that have been set aside. This, according to these scholars, applies even if the domestic laws provide more favourable rights. ${ }^{38}$ However, some scholars have contended that an annulled award ceases to exist and, as a result, there is no question of enforcing such a non-existent award. These scholars have stressed that Article VII does not pertain to annulments and merely applies to the other grounds of non-enforcement specified under Article V. ${ }^{39}$

The term "may" in Article V of the Convention seems to empower a court to enforce a foreign arbitral award that has been set aside. ${ }^{40}$ Ostensibly, Article V applies to all the stipulated grounds, including annulment. It has been strongly contended that if the drafters of the New York Convention had been desirous of categorising annulment as an exception requiring non-enforcement, such exception would have been made explicit. ${ }^{41}$ It is paramount to mention that arbitration law in the Middle East has had significant effects on the resolution of disputes both in local trade as well as in international business. A detailed look at how arbitration law has been used to resolve disputes in Kuwait has been given priority in this article.

\section{Arbitration Law in Kuwait}

The dispute resolution mechanism in Kuwait differentiates between foreign and domestic arbitral awards. This section identifies and analyses the way in which Kuwait's laws operate and the impact that this is likely to have on the recognition and enforcement of arbitral awards in Kuwait. Any application relating to the enforcement of an arbitral award made in Kuwait also has to be made with the court that initially exercised jurisdiction over that case. This court provides an execution order only after confirming the existence of a valid arbitration clause, the absence of a right to appeal, and a justification for enforcing the award.

The merits of the dispute cannot be reconsidered by the court at the time of examining the award. Under the provisions of the CCCP, Kuwaiti courts enforce foreign arbitral awards that have been rendered in a member state of the NYC. ${ }^{42}$ The arbitral award of a non-signatory nation will be enforced in Kuwait if there is mutuality of enforcement between these countries. Under the provisions of the CCCP, Kuwaiti courts will enforce arbitral awards without examining the merits of the case or retrial under the following circumstances: first, Kuwaiti law can resolve the dispute by arbitration; second, the arbitral award can be enforced in the jurisdiction where it had been rendered; and third, there has been compliance with the procedural requirements. ${ }^{43}$

A foreign arbitral award can be enforced in Kuwait provided there is reciprocity. It is not very difficult to enforce a foreign arbitral award in this country, due to the fact that reciprocity can be established without great difficulty. This is on account of Kuwait having ratified the NYC. ${ }^{44}$ This was achieved by the enactment of legislation. ${ }^{45}$ Consequently, a foreign arbitral award can be enforced in Kuwait if the nation in which the award had been issued is a member of the Convention. In addition, the dispute should be such that it can be arbitrated in accordance with the law of Kuwait. Furthermore, it should not be capable of being classified as criminal conduct under Kuwait law or contravene mandatory provisions. ${ }^{46}$

In 1995, Kuwait enacted the JAL, already discussed above, whose aim is to promote the arbitration process. ${ }^{47}$ As specified in this law, the panel enjoys jurisdiction over the following issues: ${ }^{48}$ any arbitration in which the disputing parties agree to refer to the panel of arbitrators; any arbitration issues that relate to a contractual dispute wherein the parties had not stipulated some other panel in the agreement relating to arbitration; disputes involving public juristic entities; and disputes between private and public juristic entities. Individuals and corporate entities

\footnotetext{
37 ibid 67.

38 ibid 76.

39 ibid 80.

40 ibid 59.

41 ibid 81.

${ }^{42}$ Kuwait Code of Civil and Commercial Procedure, art 199.

43 KR Davis, 'Unconventional Wisdom: A New Look at Articles V and VII of the Convention on the Recognition and Enforcement of

Foreign Arbitral Awards' (2002) 37 Texas International Law Journal 43.

${ }^{44}$ International Business Publications, Kuwait Company Laws and Regulations Handbook (Int'1 Business Publications 2008 ) 44.

45 Kuwait Arbitration Law no. 10 of 1998.

46 International Business Publications, Kuwait Company Laws and Regulations Handbook (Int'1 Business Publications 2008$) 44$.

47 Kuwait Arbitration Law no. 10 of 1995.

48 ibid art 2.
} 
have the freedom to take their dispute to the court or to compel the government entity to undergo judicial arbitration. ${ }^{49}$

The 1995 legal provision established in Kuwait is a particularly formative stage in the enforcement of arbitral awards as it attempts to find a balance between the need to allow traders the freedom to establish their own rules and the need for Kuwait to establish rules and regulations that offer certainty within the international arena. This desire to gain recognition across the international arena with particular reference to foreign trade relations has been the backbone of the development of the statutory rules associated with arbitration across Kuwait.

Kuwait enjoys an economy that is primarily based on trading. Over time, the customs and procedures associated with such trading have emerged as clearly defined business practices that are regulated by the law of the land. Another important feature of the trading scene in Kuwait is the competence possessed by the traders and companies in the law relating to commerce. The Commercial Companies Law governs companies and commercial entities, and the entrepreneurs of Kuwait display considerable knowledge of this law. ${ }^{50}$

Conventions relating to international commercial arbitrations not only eliminate reciprocity requirements but also resolve the issue of enforcing foreign judgments. A foreign arbitral award can be recognised and enforced effectively and with comparative ease by the technique of concluding a convention. The legal frameworks of the various states are very divergent. Consequently, conventional codification serves to hinder the adoption of suitable rules which in turn increases the ineffectiveness of the process.

Kuwait's arbitration law does not differentiate or discriminate between international arbitration and domestic arbitration. ${ }^{51}$ The parties forming part of a contractual agreement which is submitted to arbitration when a dispute arises in commercial transactions are free to choose and contract to the particular laws relevant to their situation. It is also advantageous that Kuwait recognises another form of arbitration, "judicial arbitration", where the government is trading under its commercial capacity. ${ }^{52}$

The JAL ${ }^{53}$ defines when an arbitral tribunal ought to have at least two arbitrators appointed by the disputing parties, or when to have three judges to be appointed by the Supreme Judicial Council. ${ }^{54}$ In this respect, one can state that Kuwait laws that are used to enforce arbitral awards are the same as those used in respect of enforcement of foreign courts' arbitral awards. The procedure involved in seeking to enforce a foreign arbitral award is first commenced by filing a claim in a Kuwaiti court of law. ${ }^{55}$ There is a requirement that, before a claim is filed, the foreign arbitral award needs to be translated into Arabic and authenticated by Kuwait's Ministry of Justice. The consulate also plays a major role in the enforcement of a foreign arbitral award because the award must be consularised by the Kuwait consulate of the relevant country and also be legalised by the Ministry of Foreign Affairs in Kuwait. ${ }^{56}$ The filed foreign arbitral award must be accompanied by a copy of the arbitration agreement made by the parties to ensure that arbitration proceedings have been consented to. In Kuwait, however, when seeking to compose an arbitration tribunal there is more concern over whether the country seeking to enforce the award is developed or developing. ${ }^{57}$ This affects the enforceability of the award because interests of developing countries may be thwarted and not well looked into. There is also the risk that they are given arbitrators who are not well-qualified to conclude the interest of the parties. Kuwait recognises the fact that once an arbitral award has been finalised, it cannot be appealed to Kuwait's courts unless the parties have an express provision to appeal against the decisions of Kuwait's courts. Unlike domestic arbitral awards, foreign arbitral awards cannot be easily set aside if there is fraud and dishonesty except in circumstances where the arbitral award is inconsistent with the laws and rules of Kuwait. ${ }^{58}$ Considering the decision in Aminoil v Kuwait, ${ }^{59}$ it was held that the host country's domestic legal system was the applicable law because it is the supreme protector of all people's rights as well as the general interest of the parties. ${ }^{60}$

The findings of this case are particularly relevant to the discussions here as they look at the practical reality of the arbitration process and, in particular, the way in which the arbitration system works, especially when one of the

\footnotetext{
${ }^{49}$ International Business Publications, Kuwait Company Laws and Regulations Handbook (Int'l Business Publications 2008$) 44$.

${ }^{50}$ ibid 44.

${ }^{51}$ Kuwait Law of Judicial Arbitration 1995.

52 ibid

53 ibid

${ }^{54}$ R Clark (ed), The Dispute Resolution Review (4th edn, Law Business Research 2012) 430.

55 ibid 438 .

56 ibid 487.

57 ibid 484

58 ibid 485.

${ }^{59}$ Kuwait Arbitration Award 1892 (n 21) 1000.

${ }^{60}$ ibid 1001.
} 
parties is a government body. A dispute arose as to whether or not the arbitration clause would apply and if so how it would work alongside the need to refer to the Compensation Committee which was a term under Kuwait's Decree Law. This brought into question the issue of a direct dispute between national law and an international commercial arbitration clause. The matter was ultimately submitted to the arbitration which was seen to be a particularly important aspect of the development of arbitration in Kuwait as it considered an issue that was politically sensitive; it was also a financially important decision for the parties involved. ${ }^{61}$ Ultimately, the tribunal, although following the principles of arbitration, chose to look towards the application of Kuwaiti law with international law playing a role, but not the dominant role. This indicates a general reluctance of the Kuwaiti tribunal to fully submit to international law even if it was prepared to deal with an international commercial arbitration clause in a transnational way.

A distinctive feature in arbitration is the review of arbitral awards enforceable in Kuwait, especially from foreign courts. The laws in Kuwait ${ }^{62}$ and also in international law provide various grounds for the review of an arbitral award and one can say that they are narrow; ${ }^{63}$ this adoption by Kuwait restricts a party's grounds to seek review. An error in law ${ }^{64}$ is not grounds for review. Even though one could argue that the parties ought to choose the forum to determine their disputes, this should be included as grounds for nullification of an arbitral award. This would be crucial in avoiding gross and negligent legal errors going uncorrected in arbitral awards. ${ }^{65}$

Arbitration awards in countries whose law is based on Sharia law have to consist of a description of the dispute, the facts as determined under Sharia, the rationale behind the award with reference to Sharia, and the decision. Sharia law, however, has a close association with arbitration law and has been recognized by sources, such as the Qu'ran, Idjma, Sunna and Qiyas. There is a major difficulty associated with these countries, with regard to arbitral awards. These countries make it compulsory for arbitration awards to be reviewed and approved by the courts. ${ }^{66}$

This situation has been rectified in Kuwait, to some extent, by the ratification of the NYC. The latter has limited the grounds on which domestic courts can reject a foreign commercial arbitral award. Nevertheless, the NYC permits the rejection of such awards if their enforcement is against the public policy of that nation. This exception has been utilised by a large number of Middle Eastern countries to reject foreign arbitral awards. ${ }^{67}$

The present level of arbitration in Kuwait has been the culmination of a gradual process. Initially, arbitration was made available in the CCCP. This code was enforced by enactment of legislation. ${ }^{68}$ Arbitration was also addressed by the JAL. ${ }^{69}$ Thereafter, another law was enacted in 1980 for the promulgation of the CCCP. ${ }^{70}$ This code is $^{\circ}$ distinguished by a number of features. First, there is no description of the disputes that can be brought before it for arbitration. The only specification is that the parties should consent to conciliation. Second, the disputed issue has to be stipulated in the contract or in the arbitration agreement. Third, the arbitration parties must nominate arbitrators who have not been deprived of their civil rights and are not under seizure. ${ }^{71}$ Fourth, it is usually prohibited to contest or object to an arbitral award unless the parties have agreed in this regard before the award had been rendered. All the same, in some cases, an action for setting aside an arbitral award can be brought. Such action has to be before the court that had originally heard the case. ${ }^{72}$

JAL provides for judicial arbitration. ${ }^{73}$ It was promulgated on 19 February 1995 and has the following features. First, it specifies that a system of judicial arbitration panels should be formed. These panels consist of three representatives of the judiciary and two arbitrators. Secondly, these panels have jurisdiction over disputes in which the parties have agreed to approach the arbitration panel. ${ }^{74}$ In addition, the arbitration panels have jurisdiction over disputes between government ministries and authorities or disputes between public sector companies. Moreover,

\footnotetext{
61 “Brazilian Loans case” Brazil v. France (1929) PCIJ, Ser A, No 21.

${ }^{62}$ Code of Civil and Commercial Procedure, Ministerial Resolutions and the Civil \& Commercial Procedure Code No. 38 of 1980 , Ministerial Resolution No. 43 on Judicial Arbitration Civil \& Commercial Articles

63 PB Rutledge, 'On the Importance of Institutions: Review of Arbitral Awards for Legal Errors' (2002) 19 Journal of International Arbitration 81 .

64 ibid

65 S Walt, 'Decision by Division: The Contractarian Structure of Commercial Arbitration' (1999) 51 Rutgers Law Review 369.

${ }^{66}$ Weinberg Wheeler Hudgins Gunn \& Dial, 'Recent Developments in Arbitration Law in the UAE' (15 September 2010)

$<$ http://www.wwhgd.com/news-article-71.html> accessed 18 March 2014.

67 ibid

68 Kuwait Law Decree no. 38 of 1980

${ }^{69}$ Kuwait Arbitration Law no. 11 of 1995.

70 Law Decree 1980 (n 38).

71 ibid

72 ibid

73 Kuwait Arbitration Law no. 11 of 1995.

74 ibid
} 
the panels enjoy jurisdiction over semi-mandatory issues or disputes between private entities and government authorities. ${ }^{75}$ Thirdly, a resolution by the Minister of Justice stipulates that the arbitrator should be a Kuwaiti national. ${ }^{76}$ In addition, the arbitrator should be well-behaved, enjoy a good reputation, and should possess the necessary academic qualifications and practical experience. Fourthly, a specific process has been described for resolving disputes by the arbitration panels. The Court of Causation can be approached if a party wishes to contest the award of the arbitration panel. Lastly, the award of the arbitration panel has the same force as an adjudged matter. Such awards are enforceable with immediate effect.

The principal duty of judges and arbitrators is not restricted to interpreting the law. It also extends to resolving disparities between the laws applicable to disputes. If the possibility of effecting remedies to the legal procedures arises during the settlement of a dispute by arbitration, then the arbitrator or judge has to decide certain important issues related to these remedies. ${ }^{77}$ These issues include whether the clause is generally prohibited, whether it is permitted, whether it is subject to specific conditions, or whether it imposes any negative consequences. It also needs to be ascertained whether the principle of the selection of jurisdiction by the parties interferes with the decision and whether the decision would be in direct or indirect conflict with legal provisions. However, there always exists the possibility that arbitral decisions could generate two parallel curial systems. At a bare minimum, the procedural laws of the place where the arbitration takes place will be in conflict with the law that prevails over the arbitration clause. ${ }^{78}$

Kuwaiti law permits parties to negotiate and include arbitral terms in their commercial contract agreements. Consequently, the majority of agreements in which a Kuwaiti is a party could incorporate arbitration clauses. These would be as per the stipulations of the Commercial Arbitration Centre of the Kuwait Chamber of Commerce and Industry (KCAC), the ICC, or some other arbitral forum. The model law of the UNCITRAL is applied by the $\mathrm{KCAC}$ when there are no provisions regarding a specific issue. ${ }^{79}$

The JAL provides additional rules and the disputing parties could engage in arbitration on the basis of the JAL. Arbitration is undertaken by the Court of Appeal's arbitration councils if the parties had agreed that the JAL would apply to their disputes. Moreover, these arbitration councils hear disputes where no arbitral body has been specified. As such, arbitration councils have exclusive jurisdiction with respect to disputes involving governmental agencies where no prior arbitration agreement had been identified as the appropriate dispute resolution mechanism. ${ }^{80}$ This is important, especially where disputes occur between state-owned companies and governmental agencies. The rules of the CCCP chiefly relate to domestic arbitration. However, Articles 199 and 200 of the CCCP govern the enforcement of foreign arbitral awards. In instances where the provisions of the JAL do not apply, the applicable rules will be that of the CCCP. ${ }^{81}$

The Middle Eastern countries that are signatories and have ratified the NYC have had to enact legislation relating to the enforcement of arbitral awards. This Convention has to be supplemented with additional domestic legislation. In order to provide guidance in this area, the UNCITRAL made available its Model Law on International Commercial Arbitration. However, the Model Law is not complete and requires legislation at the national level. Most of the nations of the Middle East have not enacted such legislation. Chief among these is Saudi Arabia which does not codify its policies, thus allowing for subjective judgements. It is therefore quite difficult to predict the outcome of any litigation. ${ }^{82}$

The option to reject an arbitral award that violates public policy has been provided under the Model Law. ${ }^{83}$ Although, every nation is justified in rejecting an award that violates its public policy, it becomes difficult to define public policy with respect to a commercial dispute. ${ }^{84}$ Considerable thought and debate was devoted to what constitutes public policy by the scholars of the Western nations. However, no consensus could be achieved and it was left to the courts to distinguish between domestic and international public policy. The courts decided only to

\footnotetext{
${ }^{75}$ ibid

${ }^{76}$ Kuwait Ministry of Justice Resolution 43 of 1995.

${ }^{77}$ Bantekas I, 'The Proper Law of the Arbitration Clause: A Challenge to the Prevailing Orthodoxy' (2010) 27(1) Journal of International Arbitration 1 .

78 ibid 6.

${ }^{79}$ Kuwait Arbitration Law no. 10 of 2008.

${ }^{80}$ ibid

81 ibid

82 K Thomas, 'Arbitrating Disputes with Middle Eastern Entities' (2010) 39(2) International Law News 8.

${ }^{83}$ Model Law, Art. 34 (2)(b)(i).

${ }^{84}$ K Thomas, 'Arbitrating Disputes with Middle Eastern Entities' (2010) 39(2) International Law News 8.
} 
apply those principles of policy that were recognised globally. The pioneer in this area was France, which included this precept in its Code of Civil Procedure. This was followed by Italy, Portugal, Algeria and Lebanon. ${ }^{85}$

Kuwait has consistently honoured its international treaty commitments. To this end, it has made it very clear that it would grant greater importance to such commitments than to its domestic laws. All the same, when it comes to enforcing foreign arbitral awards, Kuwait can and does protect domestic interests when such protection favours public policy. ${ }^{86}$ The enactment of the Kuwaiti Commercial Code Provisions is vital to the protection of distributors who can be affected by the termination of foreign distributorship agreements by a foreign company. ${ }^{87}$

It is not clear whether Kuwaiti courts will reject foreign arbitral awards on grounds of public policy. Sharia law includes several rules that prohibit interest and risk. Consequently, Middle Eastern countries whose laws are based on Sharia law face considerable confusion in enforcing foreign arbitral awards that relate to interest and insurance. There is a marked difference between the principles of Sharia law and modern international commercial law. Thus, the nations that follow Sharia law face great difficulty and confusion in enforcing foreign arbitral awards. ${ }^{88}$

Despite these differences and the general reluctance of the Arab states to accept international conventions in relation to international arbitration, there is a growing need to consider the way in which foreign judgments could be enforced in the Arab states. One particular difficulty that emerges is the fact that states are generally reluctant to enforce an agreement which may later be overruled; where there are differences in the rules of law there is also likely to be a reluctance to enforce foreign judgments. It is noted therefore that the recognition of an arbitral award will be subject to strong procedural rules if they are to be relevant and usable within the Arab states that are fundamentally reluctant to fully accept the rules associated with international arbitration and the acceptance of awards that have been established by a foreign court.

The nations of the Middle East that have not acceded to the NYC enforce foreign commercial arbitral awards on the basis of their national legislation. Kuwait is one of the few nations of this region that have ratified the NYC. It has achieved this by means of specific procedures that have been stipulated in its Civil and Commercial Procedures Act. ${ }^{89}$ Subsequent to ratifying the NYC, Kuwait enacted a law that reorganized the relevant civil and commercial procedures. ${ }^{90}$ This law addresses arbitration. ${ }^{91}$ Nevertheless, Kuwait prohibits its ministries, public authorities and state companies from undertaking arbitration to resolve disputes with individuals or legal entities. ${ }^{92}$

This injunction was the subject matter of a cabinet decision in $1988 .{ }^{93}$ This decision made it very clear that such bodies were precluded from incorporating arbitration clauses in contracts. In addition, it required such contracts to specify that dispute resolution was to be solely undertaken by Kuwaiti courts and the applicable law was the law of Kuwait. ${ }^{94}$

An increase in international commercial disputes has been matched by an increase in the employment of the arbitration process to resolve such disputes. Arbitration is devoid of a judicial nature and this explains its effectiveness and appeal. A non-judicial system is preferred because of the intricacy, cost and protracted nature of commercial disputes that are settled in a foreign court. Moreover, the decision of a foreign court is latently unenforceable. ${ }^{95}$ Thus, arbitral awards enjoy great popularity as is evident from the large number of nations that have agreed to adhere to the terms of the NYC. Arbitration as a technique for resolving commercial disputes has been promoted by several international conventions, treaties and agreements. In the past, only a few countries had enforced efficient arbitration systems; many of the countries had laws that interfered with arbitral awards, thereby diminishing the effectiveness of these awards. Moreover, many national legal systems had failed to enforce arbitral judgements. $^{96}$

85 ibid

86 ibid

${ }^{87}$ Kuwait Commercial Code, arts. 281-282.

88 K Thomas, 'Arbitrating Disputes with Middle Eastern Entities' (2010) 39(2) International Law News 8.

${ }^{89}$ HM Al-Baharna, 'International Commercial Arbitration in Perspective' (1988) 3(1) Arab Law Quarterly 19883.

90 Kuwait Arbitration Law no. 38 of 1980.

91 ibid

92 K Alhamidah, 'Administrative Contracts and Arbitration, in Light of the Kuwait Law of Judicial Arbitration No. 11 of 1995' (2007) 21(1)

Arab Law Quarterly 35.

93 Kuwait Cabinet Decision no. 11 of 1988.

94 K Alhamidah, 'Administrative Contracts and Arbitration, in Light of the Kuwait Law of Judicial Arbitration No. 11 of 1995' (2007) 21(1)

Arab Law Quarterly 35.

95 G Miccioli, 'International Commercial Arbitration' (ASIL, 14 August 2013) < http://www.asil.org/sites/default/files/ERG_ARB.pdf $>$

accessed 18 March 2014

96 ibid 
This undesirable situation changed in 1976, with the adoption of the arbitration rules of the UNCITRAL. Its arbitral rules can be utilised by any private or public entity that desires to arbitrate independently of an international arbitral institution. In considering the arbitration in Kuwait, the laws that govern the arbitration process and procedure came into effect in $1980^{97}$ with many scholars stating that it had been brought in too soon. ${ }^{98}$ The previous law governing arbitration in the country was not that bad but it had faults, especially in its laws of procedure, and it was mainly those who were dissatisfied by the awards who went to the courts to seek redress. ${ }^{99}$ As a consequence of this, there was a backlog in settling disputes that had been arbitrated on; hence, the new law was a welcome idea.

The laws governing arbitration and arbitral awards are mainly based on the CCCP, with Article 173 laying down the rules on arbitration. This Code has been critical in determining how enforcement of arbitral awards are to be determined as well as a basis for setting aside, recognition and enforcement of foreign arbitral awards. ${ }^{100}$ Internationally, there are many bodies set up to effectively deal with arbitration, such as the ICC, the Arbitration Institute of the Stockholm Chamber of Commerce, and the International Court of Arbitration. They all have their own procedures of arbitration. This is mainly attributed to the fact that it has harmonised its laws in order not to create a conflict when the question of jurisdiction arises. ${ }^{101}$ Kuwaiti laws on arbitration are not harmonised and they have reservations on how the NYC applies to them. This creates a platform for conflict when it comes to enforcing arbitral awards from states that do not reciprocate the awards of Kuwait or those that do not recognise and enforce Kuwaiti arbitral awards. ${ }^{102}$

Similar problems and issues have arisen in the English legal system and with the way in which the English courts have dealt with the disputes associated with the proper law of an arbitration clause. It is noted by academics that although there are multiple ways in which the proper law can be ascertained, there is no practical or legal reason for these not to work together or to work interchangeably depending on the nature of the dispute in question.

The proper law of the arbitration agreement, based on contractual interpretations, has some practical use for those looking to deal with an arbitration and therefore to offer greater security to the enforceability of these awards. It is argued, therefore, that whilst there needs to be a degree of flexibility afforded to the various different arrangements that may be entered into between the parties, consideration should be given to whether or not the use of the proper contractual legal principles should apply in certain situations. This would, however, require a degree of harmonisation which has yet to be achieved in Kuwait's domestic law. An arbitral award is rejected by Kuwaiti law if it contradicts a previous ruling of a Kuwaiti court, or is against morality or public order. Under this law, a foreign jurisdiction can be selected by the contracting parties, with regard to their agreement, in order to resolve disputes related to such agreement. This clearly depicts a glaring absence of harmonisation in the context of the enforcement of international commercial arbitral awards.

The success of arbitration is influenced to a large extent by the domestic law of a nation. Due to this, the parties to arbitration have to consider whether international or regional treaties are upheld by the enforcing nation. In addition, these parties have to take into account the capacity of the competent court to enforce arbitral awards. Arbitration, as a principle, is not new to Arab countries such as Kuwait, as it is enshrined within the Islamic, Sharia legal system. The concept of arbitration has been mentioned as part of the Koran; therefore, it can be argued that arbitration was, in fact, deeply-rooted within the Arab countries long before any integration happened with the Western countries. The issue associated with arbitration and, in particular, with the ability to refer to arbitration when international commercial disputes arose was something that became highly relevant in Kuwait during the 1940s, when the travel industry within the region began to grow. It is worth noting that rules associated with arbitration and the way in which commercial parties will undertake negotiations changes as the underlying economic conditions also change. In this case, the growth of the oil industry within Kuwait has made it necessary to consider how Kuwait should deal with international challenges.

Arguably, it is this drive to become more economically efficient and the recognition that international operations are a fundamental part of the economic development of the region that has led to arbitration being formally recognised by Kuwait. As part of this critical analysis of how arbitration is enforced within Kuwait, it is crucially important to identify how Kuwaitis deal with traditional arbitration, in the first place, and the perceived advantages

\footnotetext{
${ }^{97}$ Kuwait Civil and Commercial Procedure Code 1980.

98 Isa A Huneidi, 'Arbitration Under Kuwait Law' (1989) 4(1) Arab Law Quarterly 20.

${ }^{99}$ ibid

${ }^{100}$ P Nacimiento, 'New law on civil and commercial arbitration' (1996) International Commercial Litigation 46.

101 C Drahozal, 'Commercial norms, commercial codes and international commercial arbitration' (2000) 33 Vanderbilt Journal of Transnational Law 79.

${ }^{102}$ Mohsin S Khan, 'Islamic Interest-Free Banking: A Theoretical Analysis' (1986) 33 Int'l Monetary Fund Staff Papers 5.
} 
that are associated with arbitration. This is because a background understanding will offer explanations as to why certain judicial decisions are enforced in Kuwait and the difficulties that arise in attempting to enforce arbitral judgements within Kuwait for nationals of this state.

Interestingly, one can argue that arbitration is part of Islamic principles and these treat the arbitrator as a respected member of society. For example, a religious individual is able to make judgments based on any disputes that arise with commerce or property. This was undertaken in a relatively simple yet effective way across Kuwait. However, with the change to the economy, arbitration has placed demands on the legislature and many statutes have been enacted which recognise the need to put traditional arbitration on a more formal footing and in order to ensure greater recognition on an international level. The major development in this regard was when Kuwait joined the NYC.

By analysing the legal structure in relation to arbitration in Kuwait and how it has developed over the years, it can be argued that arbitration broadly falls into one of four categories. Firstly, there is optional arbitration where the parties may include clauses in their contracts to submit themselves to arbitration in the event of a dispute. Secondly, there is institutional arbitration where certain aspects of trade, such as the stock market, are submitted to an institutional arbitration that it cannot choose to opt out of. Thirdly, there is international arbitration where, although there is no fundamental distinction between national and international arbitration, in Kuwait, it is generally referred to as any arbitration that falls outside of Kuwait and where Kuwait has agreed to recognise foreign arbitral awards, to a certain extent, thus bringing international arbitral awards within the ambit of Kuwaiti law. Finally, there is judicial arbitration which is undertaken by the Ministry of Justice. This has recently been amended and therefore it forms a fundamental part of this analysis as it is one of the more recent developments in the recognition of arbitral awards in Kuwait.

Throughout this analysis, it became apparent that one of the major difficulties associated with the use of arbitration in Kuwait was its complexity and that, traditionally, arbitration was referred to as a means of dealing with commercial disputes in an efficient and private manner. However, when such complexities are included within the system, many of the advantages associated with arbitration are simply lost. It was with this in mind that the judicial arbitration, as regulated by law number 11/1995, established several key concepts that were incorporated into the law in Kuwait. This was not necessarily undertaken with a view to increasing harmonisation with international principles but rather to ensure that the key benefits associated with arbitration were felt within Kuwait. It was, therefore, in a much more stable position to enforce foreign arbitral awards where appropriate.

The precise procedures and rules have been discussed above. However, for the purpose of this analysis, it is necessary to look at the effect of these rules and to ascertain the impact that these have had on the enforcement of arbitral awards across Kuwait. The legal system which has been established in order to deal with the use of arbitration in Kuwait allows for arbitration of a mixed nature and encourages, as far as possible, the ability of the parties to use their own free will in order to resort to arbitration, while also maintaining the parties' autonomy as far as possible. This willingness to use an arbitration agreement is an important part of ensuring success within the arbitral system as it is argued that enforcement will be considerably easier for both parties entering into arbitration by their own free will.

On the whole, therefore, it is argued that one of the fundamental difficulties associated with ensuring the enforcement of arbitral awards across Kuwait is the willingness of Kuwait to become part of an international community, in terms of trade, and this requires the Kuwaiti government to put in place statutory requirements that offer certainty and finality over arbitral awards, whether they are national or international in nature. It is this continuous desire to harmonise and to become part of the international community that will ultimately lead to greater certainty in the area of the enforcement of arbitral awards.

Arbitration is known since time immemorial as a mechanism for solving disputes peacefully as opposed to through litigation procedures. It has also been accepted universally as being quite cost effective, private, consensual, and the awards are usually considered to be binding on all parties to the arbitration agreement. ${ }^{103}$ In practice, arbitration is usually considered to be crucial based on the freedom of contract that the parties are given as regards the enforcement and granting of an arbitration agreement. ${ }^{104}$ It has various rules of procedure that govern its recognition and enforcement especially if it is considered as a foreign arbitral award under the laws of Kuwait. ${ }^{105}$

\footnotetext{
103 A Redfern and M Hunter, Law and practice of international commercial arbitration (4th edn, Sweet \& Maxwell 2004).

$104 \mathrm{~T}$ Weiler, International Investment Law and Arbitration (Cameron 2005).

105 Alhajeri MA, 'A critical approach to the Kuwaiti Law of Judicial Arbitration no. 11 of 1995 with Reference to the UNCITRAL Model Law on International Commercial Arbitration' (2000) 15(1) Arab Law Quarterly 48.
} 


\section{Conclusion}

This article has focused on the extent to which foreign arbitral awards are enforced in Kuwait with various notable exemptions in terms of their recognition and enforceability. The main convention that has been adopted by Kuwait is the NYC and this has been domesticated in Kuwait. Notably, Kuwait has held certain reservations as regards the NYC, hence enforcing and recognising arbitration awards from different states differently.

Arbitration proceedings and their main advantages have been explained throughout the article, namely, that they save time and give disputing parties a cost-effective way to settle their disputes amicably. ${ }^{106}$ Most of the arbitrators are usually competent as well as capable of giving awards that reflect the true state of what needs to be determined in the dispute. ${ }^{107}$ Arbitration awards are not well defined in the legislative framework of the domestic laws of Kuwait but an arbitral award is usually considered to be one that is declared by the tribunal of a competent jurisdiction.

The article has gone a step further and looked into the basis of recognition and enforcement of arbitral awards as set out in the CCCP and other laws that are relevant to providing the procedural law as well as the substantive law that governs the recognition and enforcement of foreign arbitral awards in Kuwait. ${ }^{108}$ In this regard, the article has identified that international law principles as well as treaties inform the way in which Kuwait arbitration awards are enforced and recognised. Although Kuwait has ratified the NYC, its provisions have not been adopted wholly; Kuwait holds a reservation on Article 1(3) but holds no reservations under those that govern arbitration agreements that involve commercial transactions. ${ }^{109}$

The article has also looked into the whole process of enforcement and recognition of foreign arbitral awards in Kuwait in relation to the grounds that give rise to the denial of recognition and enforcement. The main ground is that of public policy, i.e., that an arbitral award cannot be recognised if it fails to meet the threshold set out in the NYC or in Sharia law. ${ }^{110}$ The detail over what public policy actually entails is left to Kuwait to determine because neither the $\mathrm{NYC}^{111}$ nor the Model law provides for what should be considered as the minimum threshold of public policy. ${ }^{112}$

The arbitrability of the arbitration dispute has been presented in the article as a major issue in Kuwait arbitration and enforcement procedures, as it also gives the place of arbitration or jurisdiction where the dispute will be heard. ${ }^{113}$ As explained, the subject matter of the dispute to be arbitrated is also considered when considering the arbitrability of the dispute. ${ }^{114}$ The lex arbitri, the proper law of arbitration, also has an impact on whether the dispute is arbitrable or not as well as the issues of fraudulent activities in the formation of the arbitration agreement and corrupt practices. ${ }^{115}$

It has been observed that refusal of enforcement is a crucial factor in the recognition and enforcement of arbitral awards in Kuwait based on issues such as reciprocity and whether the arbitral award is consistent with international law and Kuwaiti law. ${ }^{116}$ The procedures that are to be considered when enforcing and recognising a foreign arbitral award ${ }^{117}$ have also been noted to be important. ${ }^{118}$ As such, Kuwait recognises and enforces foreign arbitral awards under certain circumstances. All the same, Kuwaiti courts are empowered to reject a foreign arbitral award. Such refusal is on the grounds of absence of reciprocity and being contrary to public policy.

The recognition and enforcement of foreign arbitral awards under the NYC regime and the enforcement system in the GCC countries have been shown to be quite different. The GCC countries reject foreign arbitral awards on the

\footnotetext{
106 K Thomas, ‘Arbitrating Disputes with Middle Eastern Entities' (2010) 39(2) International Law News 8.

107 Teson FR, 'State Contracts and Oil Expropriations: The Aminoil-Kuwait Arbitration' (1984) 24 Virginia Journal of International Law 323.

108 J El-Ahdab, Arbitration with the Arab Countries, (3rd edn, Kluwer Law International 2011).

109 E Gaillard and J Savage, Fouchard Gaillard Goldman on International Commercial Arbitration (2nd edn, Kluwer Law International 1999).

${ }^{110}$ H Kronke, P Nacimento \& D Otto, Recognition and enforcement of foreign arbitral awards: a global commentary on the New York Convention (Kluwer Law International 2009) 365.

111 NYC, art. V (2) (b).

112 KP Berger, International economic arbitration (Kluwer Law and Taxation Publishers 1993) 726.

113 A Sheppard, 'Interim ILA report on public policy as a bar to enforcement of international arbitral awards (2003) 19(2) Arbitration International 217.

114 A Redfern and M Hunter, Law and practice of international commercial arbitration (4th edn, Sweet \& Maxwell 2004) 138.

115 CN Brower \& JK Sharpe, 'International Arbitration and the Islamic World: The Third Phase' (2003) American Journal of International Law 97(3) 643.

116 G Born, International Commercial Arbitration (Kluwer Law International 2009) 1065.

117 Code of Civil and Commercial Procedure, art. 177-200.

118 A Redfern and M Hunter, Law and practice of international commercial arbitration (4th edn, Sweet and Maxwell 2004$) 2$.
} 
basis of domestic public policy and not international public policy. This has been justified by these countries on the grounds that their domestic laws are based on Sharia law and this reflects their culture. It has been observed that the extant legislative regime with regards to the recognition and enforcement of foreign arbitral awards in Kuwait does not function satisfactorily to the fullest extent and, therefore, the legislation of Kuwait is still subject to Islamic law.

On the other hand, it has been noted that Kuwait has legislation that is developed to a considerable extent in spite of the fact that its Civil Code is based on Islamic Sharia law. Consequently, it has been argued that Sharia law has tremendous influence even on international arbitration, something which could prove disadvantageous to a businessman or corporation from a non-Islamic nation.

\section{References}

1907 Convention for the Pacific Settlement of International Disputes (Hague I) [1997] ATS 6.

Abdullah Kh Al-Ayoub \& Associates. Enforcement of Foreign Judgments. Retrieved March 18, 2014, from http://www.al-ayoub.org/legal3.html

Al-Baharna, H. M. (1988). International Commercial Arbitration in Perspective. Arab Law Quarterly, 3(1), 3. http://dx.doi.org/10.1163/157302588X00100

Alhajeri, M. A. (2000). A critical approach to the Kuwaiti Law of Judicial Arbitration no. 11 of 1995 with Reference to the UNCITRAL Model Law on International Commercial Arbitration. Arab Law Quarterly, 15(1), 48. http://dx.doi.org/10.1163/A:1006757506581

Alhamidah, K. (2007). Administrative Contracts and Arbitration, in Light of the Kuwait Law of Judicial Arbitration No. 11 of 1995. Arab Law Quarterly, 21(1), 35. http://dx.doi.org/10.1163/026805507X197839

Aminoil v Kuwait. Kuwait Arbitration Award 1892 (n 21) 1000.

Bantekas, I. (2010). The Proper Law of the Arbitration Clause: A Challenge to the Prevailing Orthodoxy. Journal of International Arbitration, 27(1), 1.

Berger, K. P. (1993). International economic arbitration (p. 726). Kluwer Law.

Born, G. B. (2009). International Commercial Arbitration (Vol. 1). Kluwer Law International.

Brazil v. France (1929) PCIJ, Ser A, No 21.

Brower, C. N., \& Sharpe, J. K. (2003). International Arbitration and the Islamic World: The Third Phase. American Journal of International Law, 97(3), 643. http://dx.doi.org/10.2307/3109849

Clark, R. (Ed.) (2012). The Dispute Resolution Review (4th ed.). Law Business Research.

Collier, J., \& Lowe, V. (2005). Dispute Settlement in the UN Convention on the Law of the Sea. Cambridge University Press.

Convention on the Recognition and Enforcement of Foreign Arbitral Awards (1958) - drafted and submitted for signature on 10 June 1958 (UN).

Davis, K. R. (2002). Unconventional Wisdom: A New Look at Articles V and VII of the Convention on the Recognition and Enforcement of Foreign Arbitral Awards. Texas International Law Journal, 37, 43.

Drahozal, C. (2000). Commercial norms, commercial codes and international commercial arbitration. Vanderbilt Journal of Transnational Law, 33, 79.

Fulton, M. J. (1989). Commercial Alternative Dispute Resolution. Law Book Company.

Gaillard, E., \& Savage, J. (1999). Fouchard Gaillard Goldman on International Commercial Arbitration (2nd ed.). Kluwer Law International.

Geoffrey, P. (1989). Settlement of International Disputes: The "Rainbow Warrior" Affair. Commonwealth Law Bulletin, 586.

Herbert, S. (2009). Country Factsheet (2nd ed.). Dlaiss Lutz and Stibbe.

Huneidi, I. A. (1989). Arbitration Under Kuwait Law. Arab Law Quarterly, 4(1), 20. http://dx.doi.org/10.1163/157302589X00037

International Business Publications. (2008). Kuwait Company Laws and Regulations Handbook. Int'l Business Publications. 
Khan, M. S. (1986). Islamic Interest-Free Banking: A Theoretical Analysis. Int'l Monetary Fund Staff Papers, 33, 5.

Kronke, H., Nacimiento, P., \& Otto, D. (2009). Recognition and enforcement of foreign arbitral awards: A global commentary on the New York Convention. Kluwer Law International.

Kuwait Cabinet Decision no. 11 of 1988.

Kuwait Civil and Commercial Code.

Kuwait Code of Civil and Commercial Procedure no. 38 of 1980.

Kuwait Law no. 10 of 1995.

Kuwait Law no. 10 of 1998.

Kuwait Law no. 11 of 1995.

Kuwait Law no. 38 of 1980.

Kuwait Ministerial Resolution no. 43 of 1995.

Miccioli, G. (2013, August 14). International Commercial Arbitration. ASIL. Retrieved March 18, 2014, from http://www.asil.org/sites/default/files/ERG_ARB.pdf

Minister of Public Works of the Government of Kuwait v. Sir Fredrick Snow and Partners [1981] 1 Lloyd's Rep 656.

Mustill, M. J. (1989). Arbitration: History and Background. Journal of International Arbitration, 6, 43.

Nacimiento, P. (1996). New law on civil and commercial arbitration. International Commercial Litigation, 46.

Ragib, W. (1993). Hal Altahkeem Nao'min Alqada'? [Is Arbitration a type of Litigation?]. University of Kuwait Law Journal, 17(1), 131.

Redfern, A., \& Hunter, M. (2004). Law and Practice of International Commercial Arbitration (4th ed.). Sweet Maxwell.

Rothwell, D., Kaye, S., Akhatkavari, A., \& Davis, R. (2011). International law: Cases and Materials with Australian Perspectives. Cambridge University Press.

Rutledge, P. B. (2002). On the Importance of Institutions: Review of Arbitral Awards for Legal Errors. Journal of International Arbitration, 19, 81. http://dx.doi.org/10.1023/A:1015064106832

Sheppard, A. (2003). Interim ILA report on public policy as a bar to enforcement of international arbitral awards. Arbitration International, 19(2), 217.

Teson, F. R. (1984). State Contracts and Oil Expropriations: The Aminoil-Kuwait Arbitration. Virginia Journal of International Law, 24, 323.

Thomas, K. (2010). Arbitrating Disputes with Middle Eastern Entities. International Law News, 39(2), 8.

United Nations Commission on International Trade Law. (1985). UNCITRAL Model Law on International Commercial Arbitration, with amendments as adopted in 2006.

Vibhute, K. I. (1998). Waiver of State Immunity by an Agreement to Arbitrate and International Commercial Arbitration. J Bus L, 550.

Walt, S. (1999). Decision by Division: The Contractarian Structure of Commercial Arbitration. Rutgers Law Review, 51, 369.

Weiler, T. (2005). International Investment Law and Arbitration (Cameron, May 2005).

Weinberg Wheeler Hudgins Gunn \& Dial. (2010, September 15). Recent Developments in Arbitration Law in the UAE. Retrieved March 18, 2014, from http://www.wwhgd.com/news-article-71.html

\section{Copyrights}

Copyright for this article is retained by the author(s), with first publication rights granted to the journal.

This is an open-access article distributed under the terms and conditions of the Creative Commons Attribution license (http://creativecommons.org/licenses/by/3.0/). 